\title{
Renewing the Civic and Democratic Mission of Higher Education: Perspectives of Leadership
}

Heidi Whitford

Barry University, USA

\section{Recommended Citation:}

Whitford, H. (2020). Renewing the civic and democratic mission of higher education: Perspectives of leadership [Review of the book Democracy, civic engagement, and citizenship in higher education: Reclaiming our civic purpose, by W. V. Flores \& K. S. Rogers, Eds.]. International Journal of Research on Service-Learning and Community Engagement, 8(1), Article 17. https://doi.org/10.37333/001c.18587 


\title{
Renewing the Civic and Democratic Mission of Higher Education: Perspectives of Leadership
}

\author{
Democracy, Civic Engagement, and Citizenship in Higher Education: Reclaiming Our Civic \\ Purpose, edited by William V. Flores and Katrina S. Rogers. Rowman \& Littlefield. 2019. \\ ISBN-10: 1498590942. 410 pp.
}

\author{
Reviewed by Heidi Whitford \\ Barry University, USA
}

\begin{abstract}
University and center leaders have a strategic role in shaping higher education toward a mission that values democratic and civic engagement. A unique feature of this book is that most of the contributors are college and university presidents and center directors. Several chapters contribute to historical knowledge of the transformative role that higher education plays in civil society and public life. Many of the values espoused in these chapters are visions of ideals and calls to action that speak to the challenges of injustice, racism, and inequity embedded within higher education and societal structures. While many of these issues remain in our midst, we may still appreciate the hope and optimism within these ideals if our higher education and community leaders are progressing in a positive direction.
\end{abstract}

Keywords: center directors, democratic engagement, racism, service-learning

\section{Renovando la misión cívica y democrática de la educación superior: Perspectivas del liderazgo}

Los líderes de universidades y de centros académicos tiene un papel estratégico en la formación de la educación superior hacia una misión que valore el compromiso democrático y cívico. Un aspecto único de este libro es que la mayoría de los colaboradores son presidentes de universidades o directores de centros académicos. Varios capítulos contribuyen al conocimiento histórico del rol transformativo que la educación superior juega en la sociedad civil y en la vida pública. Muchos de los valores compartidos en estos capítulos son visiones de ideales y llamadas a la acción que responden a los desafíos de la injusticia, el racismo y la inequidad integrados en la educación superior y en las estructuras de la sociedad. Mientras muchos de estos asuntos siguen presentes, podemos todavía apreciar la esperanza y el optimismo dentro de estos ideales si nuestros líderes en las esferas universitarias y comunitarias progresan en una dirección positiva.

Palabras clave: directores de centros académicos, el compromiso democrático, el racismo, el aprendizaje de servicio

Editors' Note: Translation by Megan J. Myers Department of World Languages and Cultures Iowa State University, USA

Democracy, Civic Engagement, and Citizenship in Higher Education: Reclaiming Our Civic Purpose represents a unique contribution to the field of scholarly work in democratic and civic engagement in higher education. This field of scholarship covers a wide range of topics such as service-learning, community/civic engagement, and democratic engagement. Amid the ongoing political, economic, and social crises that have engulfed the United States in recent years, this volume is a welcome addition to an array of scholarly work that focuses on higher education institutions (HEIs). The editors have brought in the collective voices of university presidents and center directors. Many of the contributors were part of the Kettering Presidents 
Group, an initiative established by the Kettering Foundation. The members of this group participated in the Deliberative Democracy Exchange, which provided a platform for an ongoing dialogue that allowed a collaborative exchange of ideas among higher education executive leaders. The resulting conversations become the foundation for this book. This review will first make connections between themes in the book and prior works in civic and democratic engagement in higher education and then evaluate the book's themes.

\section{Connections to the Scholarly Field}

The overarching purpose of this book is to explore the role of HEIs in creating a better, more just society for all citizens. Scholars in this field have long questioned the role of HEIs in the realm of public life, which is continuously under pressure from social, economic, and political influences. For example, Boyte (2015), who contributed a notable chapter to the present collection, wrote an earlier work calling for greater participation in public and civic work within HEIs. The more specific angle that the present book explores is higher education executive leaders' role in shaping the direction of democracy, civic engagement, and citizenship within their institutions. Flores and Roger's edited book deftly provides an illuminating glimpse into higher education leaders' perspectives on this crucial topic.

Today, HEIs are under more pressure than ever from external and internal forces arising from economic, social, and political factors. These forces have been explored at length by other authors who took a more critical stance. Giroux (2014) and Giroux and Giroux (2004) come to mind as authors who forcefully critiqued the commodification of higher education and its decreasing role in a democratic society. To take a stand on these issues often implies a political stance, which higher education leaders usually try to avoid to maintain an appearance of neutrality. Yet, the topics tackled by the present book's authors evoke a turn toward social justice issues that have become encumbered by partisan politics brought about by the changing tides of the turbulent times in which we live.

Some authors in the field have argued in earlier works that service and service-learning are critical parts of the definition of civic engagement within higher education (e.g., Butin, 2010; Aramburuzabala et al., 2019), and some of the authors in the present book touch on these themes. While many leaders embody the values espoused in this book, they just as often find themselves bearing the brunt of protests and activism themselves. Pierce (2014) wrote extensively of college presidents becoming embroiled in conflict-filled scenarios in which college presidents themselves became targets of organized demonstrations. College presidents are at once idealized visionaries and strategic negotiators who must manage a complex multitude of competing interests and rapidly evolving situations. Birnbaum and Eckel (2005) incisively described this ongoing dilemma of the contemporary college president.

\section{Overview of the Book}

Democracy, Civic Engagement, and Citizenship in Higher Education is organized in five sections, with an Introduction in which Flores and Rogers, the editors, describe the ongoing crisis in higher education. Section I, "Rising to the Challenge," contains chapters describing how higher education changed from a public good to a consumer good. Sections II, III, and IV are focused on the voices of college and university presidents. Section II, "Voices of Presidents on Renewing the Civic Purpose of Higher Education," illustrates the challenges of moving from self-contained institutions to ones with a civic purpose. In Section III, "Voice of Presidents in Urban Settings," authors describe the strategically important role of community colleges in democratic education and the challenges of incorporating social justice and equity values into the colleges' missions. Section IV, "The Voices of Presidents on Student Learning and Democracy," represents the crucial perspective of student learning. Finally, Section V, "Theory and Practice: Views from Center Directors," provides a tangible illustration of the center directors' role as they navigate this challenging environment. 


\section{Responses to the Challenges: A Crisis of Democracy}

The first section of the book explores how HEIs have responded to the various crises described by Flores and Rogers in the Introduction. In the Introduction, they summarize the leading problems in democracy: challenges to the media, lack of voter participation, suppression of dissent and protests, and an erosion of trust in the branches of government. These multifaceted problems extend to the environment of higher education, with each college or university representing a kind of microcosm that reflects what is taking place in the larger society. The editors described how the Kettering Foundation created the College Presidents Group to create a dialogue among the executive leaders of HEIs to address these challenges at their respective institutions and to bring back the public role in civic and democratic engagement. Whereas previous works by authors such as Jacoby and Associates (2009) and Butin (2010) provided comprehensive conceptual and practical guidelines for civic engagement in higher education, this book takes on a unique angle through the contributors' perceptions.

In Chapter 1, William V. Flores and Noël Bezette-Flores describe their journey through higher education as they purposefully sought to engage in service to others through various community organizations with ties to HEIs. They also discuss the racism that they observed and experienced growing up in the United States. As two of several authors in this book to discuss racism issues directly, Flores and Bezette-Flores have brought to mind the work of Arday and Mirza (2018) who investigated systemic racism within the academy. This chapter also describes the formation of the Kettering College Presidents Group, which played a crucial role in developing the book's ideas by providing a framework and platform for the dialogue.

Chapter 2, by David Matthews, brings to the fore the connection between two simultaneous crises: one in the societal realm of democracy and the other in the milieu of higher education. Matthews argues that higher education has evolved from a public good to a consumer good and asks whether and how to return higher education to the realm of a public good with a role in democratic and civic engagement. Although Matthews paints a gloomy picture, he also espouses hope for the role that higher education can play if it can successfully navigate this transformation. In the author's view, HEI leaders need to be supported by their constituents and their partners in foundations and other HEIs to bring this movement to the forefront. This chapter evokes the theme of Giroux and Giroux's (2004) critique of the commodification of higher education as the sector has evolved from a public good into a consumer good, with less public expenditure going toward higher education.

\section{Voices of Leadership: Strategies, Visions, and Contexts}

The first section of the book explores how HEIs have responded to the various crises described by Flores One of the book's salient features is that the authors are (or were) college and university presidents and center directors. The second, third, and fourth sections provide a fascinating glimpse into the HEI leaders' perspectives and visions. While college presidents may represent a view from a lofty perch, they are, nonetheless, pivotal in shaping their institutions' direction as they move forward with new approaches in furthering a mission of democratic and civic engagement. Moreover, college presidents have access to information and data that few others have.

Another distinctive feature of this book is that it is in large part a product of cooperative dialogue among the contributors. Sean Creighton introduces this team effort in Chapter 4 by describing the framework that gave rise to the collegial exchanges among college and university presidents. Jonathan Alger and Abraham Goldberg follow in Chapter 5, calling for a renewed interest in civic engagement through the mission of HEIs. They describe how they created an Engagement Advisory Group at James Madison University to implement their vision of civic and democratic engagement within the university, and particularly within academics.

The next section of the book delves into issues related to urban campuses and community colleges. In Chapter 10, David Wilson describes how the fight for justice was part of the founding mission of an HBCU—Morgan State University, in Baltimore, Maryland. Beyond its history in the civil rights movement, 
the students of Morgan State were fighting for justice in the present day as part of the Black Lives Matter movement in the wake of the recent killing of Black citizens. Wilson further describes the "Morgan Community Mile" in Northwest Baltimore. This program provided students, faculty, and staff with opportunities to work collaboratively with community members on various projects in the area adjacent to the university campus. As president of Morgan State, Wilson describes being a participant in the activities, not just a supportive leader, and his description of these activities brings the chapter to life.

Embedding civic learning and democratic engagement concepts into the curriculum is another theme discussed extensively in the book. An example of this is found in Chapter 13, by Terrence Bensel and James Mullen, in which they describe integrating civic engagement into student learning at Allegheny College in Pennsylvania. The authors provide details of the Community Wellness Initiative, a collaborative effort of students, staff, and community members. The initiative focused on a community garden and healthy eating programs, and on providing healthy food options through a mobile farmers market to community members in need, such as those in public housing and senior centers.

In Chapter 15, Eduardo M. Ochoa describes how a relatively new HEI implemented a social equity agenda. The initiatives at California State University, Monterey Bay included an award-winning servicelearning program, a regionally focused career guidance program called Bright Futures, and Community Dialogues to offer the external community "the opportunity to discuss important issues across differences in a thoughtful, open-minded, and respectful way" (pp. 229-230). Describing the results of dialogues with community members as "varied" (p. 231), Ochoa notes that his university established a pathway for future discussions to continue building on this engagement.

The fifth section of the book offers center directors' contributions to greater democratic engagement among HEIs. These contributors represent a range of university and community centers. Chapter 17, by Windy Y. Lawrence and Bezette-Flores (with John Locke), provides one of the most compelling and useful essays in this book section. The chapter shares the experiences of two faculty members (with a student) in leading public deliberation/civic engagement centers (and a student government association). The accounts of their experiences may provide guidance and inspiration for faculty members and students alike, who aspire to similar accomplishments.

\section{Concluding Thoughts}

Democracy, Civic Engagement, and Citizenship in Higher Education contains insightful information gleaned from a careful reading of its contents. It provides inspirational essays, much like other volumes such as those by Peters et al. (2010), who similarly took a storytelling approach, and Saltmarsh and Zlotkowski (2011), whose essays encapsulated ideals related to the importance of connecting civic and democratic engagement to HEIs. As argued by Fitzgerald et al. (2012), community members and other stakeholders outside the academy should play a central role in shaping the purpose of higher education. This book admirably evokes a passionate response to this call from its contributors. This book provokes thought by describing different higher education contexts; therefore, it is incumbent on the reader to envision how the ideas might contribute to one's own institution. Although some are compelling, the chapters generally lack details of the implementation of specific initiatives, and there is scant information regarding funding and resources that many of the projects require. Several of the chapters contain idealized visions that, if those visions are to be actualized, require the full involvement of stakeholders who have competing interests. Although these visionary leaders provide excellent examples and an inspirational path forward, more is needed to empower those at the grassroots level to implement and practice the values articulated. 


\section{References}

Aramburuzabala, P., McIlrath, L., \& Opazo, H. (Eds.). (2019). Embedding service learning in European higher education: Developing a culture of civic engagement. Routledge.

Arday, J., \& Mirza, H. S. (Eds.). (2018). Dismantling race in higher education: Racism, whiteness and decolonising the academy. Springer.

Birnbaum, R., \& Eckel, P. D. (2005). The dilemma of presidential leadership. In P. G. Altbach, R. O. Berdahl, \& P. J. Gumport (Eds.), American higher education in the twenty-first century (2nd ed., pp. 340-365). Johns Hopkins University Press.

Boyte, H. C. (Ed.). (2015). Democracy's education: Public work, citizenship, and the future of colleges and universities. Vanderbilt University Press.

Butin, D. (2010). Service-learning in theory and practice: The future of community engagement in higher education. Springer.

Fitzgerald, H. E., Bruns, K., Sonka, S. T., Furco, A., \& Swanson, L. (2012). The centrality of engagement in higher education. Journal of Higher Education Outreach and Engagement, 16(3), 7-28.

Giroux, H. A. (2014). Neoliberalism's war on higher education. Haymarket Books.

Giroux, H. A., \& Giroux, S. S. (2004). Take back higher education: Race, youth, and the crisis of democracy in the post-civil rights era. Macmillan.

Jacoby, B., \& Associates. (2009). Civic engagement in higher education: Concepts and practices. JosseyBass.

Peters, S. J., Alter, T. R., \& Schwartzbach, N. (2010). Democracy and higher education: Traditions and stories of civic engagement. MSU Press.

Pierce, S. R. (2014). Governance reconsidered: How boards, presidents, administrators, and faculty can help their colleges thrive. Jossey-Bass.

Saltmarsh, J., \& Zlotkowski, E. (2011). Higher education and democracy: Essays on service-learning and civic engagement. Temple University Press.

\footnotetext{
About the Author

Heidi Whitford is an associate professor in the Adrian Dominican School of Education at Barry University (Miami, FL, USA).

Correspondence concerning this article should be addressed to Heidi Whitford at hwhitford@barry.edu.
} 